\title{
Transferability and use of microsatellite markers for the genetic analysis of the germplasm of some Arachis section species of the genus Arachis
}

\author{
Juliana Pereira Bravo ${ }^{1}$, Andrea Akemi Hoshino ${ }^{1}$, Carla Maria Lara C.D. Angelici ${ }^{1}$, \\ Catalina Romero Lopes ${ }^{1}$ and Marcos Aparecido Gimenes ${ }^{1,2}$ \\ ${ }^{1}$ Universidade Estadual Paulista - UNESP, Laboratório de Biotecnologia e Genética Molecular, \\ Departamento de Genética, Instituto de Biociências, Botucatu, SP, Brazil. \\ ${ }^{2}$ Instituto Agronômico de Campinas, Campinas, SP, Brazil.
}

\begin{abstract}
The Arachis section is the most important of the nine sections of the genus Arachis because it includes the cultivated peanut, Arachis hypogaea. The genetic improvement of $A$. hypogaea using wild relatives is at an early stage of development in spite of their potential as sources of genes, including those for disease and pests resistance, that are not found in the A. hypogaea primary gene pool. Section Arachis species germplasm has been collected and maintained in gene banks and its use and effective conservation depends on our knowledge of the genetic variability contained in this material. Microsatellites are routinely used for the analysis of genetic variability because they are highly polymorphic and codominant. The objective of this study was to evaluate the transferability of microsatellite primers and the assay of genetic variability between and within the germplasm of some species of the Arachis section. Fourteen microsatellite loci developed for three different species of Arachis were analyzed and 11 (78\%) were found to be polymorphic. All loci had transferability to all the species analyzed. The polymorphic loci were very informative, with expected heterozygosity per locus ranging from 0.70 to 0.94 . In general, the germplasm analyzed showed wide genetic variation.
\end{abstract}

Key words: genetic diversity, germplasm, peanut, transferability, wild species.

Received: November 23, 2004; Accepted: November 11, 2005.

\section{Introduction}

The genus Arachis L. is composed of 69 described species distributed into nine taxonomic sections (Krapovickas and Gregory, 1994). The most studied section of the genus is the Arachis section containing 27 species (Krapovickas and Gregory, 1994) including the cultivated peanut (Arachis hypogaea L.), a South America native species which the evidence suggests has its center of origin in Bolivia, where the wild diploid species which are its putative progenitors are found (Gregory et al., 1980; Kochert et al., 1996). Three Arachis species genomes (A, B and D) are known based on chromosomal morphology and crossing relationships, the cultivated peanut being an allotetraploid (AABB) that arose through a single event involving hybridization between two wild diploid section Arachis species, A. duranensis (the A genome) and $A$. ipaënsis (the B genome) (Kochert et al., 1996).

Although the use of wild relatives for the genetic improvement of $A$. hypogaea has been investigated for a large

Send correspondence to Marcos Aparecido Gimenes. Instituto Agronômico de Campinas, Caixa Postal 28, 13001-970 Campinas, SP, Brazil. E-mail: gimenes@iac.sp.gov.br. number of agronomic traits and wild species have occasionally been used as a source of genes for the genetic improvement of cultivated peanut (Singh et al., 1996; Simpson and Starr, 2001; Burow et al., 1996) breeding programs have typically been undertaken using standard techniques and have only explored the primary gene pool (Garcia et al., 1995).

Microsatellite markers are made up of tandemly repeated sequences of one to six nucleotides (Weber and May 1989) and have been widely used to evaluate genetic variability in plant species (Ghebru et al., 2002; Hormaza, 2002). Gupta and Varshney (2000) have pointed out that microsatellites have many advantages over other types of markers, including high polymorphism, random distribution in eukaryotic genomes and high frequency, while Plieske and Struss (2001) have shown that microsatellite markers developed for one species can also be used in related species with no additional cost for primer development, a serious restriction to the wider use of microsatellites. Microsatellites also allow easier data integration because they are amplified by using very stringent 
polymerase chain reaction (PCR) conditions and, generally speaking, only single loci are amplified.

Germplasm of most wild Arachis species has been collected and maintained in various germplasm banks. An assay of the genetic variability of this germplasm is very important for its most effective use in breeding programs and for its conservation, since knowledge of genetic variation can help in regeneration, the identification of duplicates and the detection of collection sites with high local variability.

Börner et al. (2000) used nine microsatellites to evaluate the genetic integrity of Triticum aestivum $\mathrm{L}$. germplasm that had been regenerated up to 24 times, demonstrating that microsatellites can be used to analyze seed bulks that had been stored at room temperature in a seed reference collection for more than 50 years. No contamination due to foreign pollen or incorrect handling during the multiplication cycles was discovered and genetic drift was observed for only one accession, showing that microsatellites can be used as a simple and reliable marker system for the verification of the integrity and genetic stability of germplasm bank accessions.

The aim of this study was to evaluate the transferability of microsatellite markers and the genetic variability in the germplasm of wild species of the Arachis section of the genus Arachis in order to contribute the conservation and better use of this germplasm.

\section{Material and Methods}

\section{Biological material}

Table 1 lists the 60 Arachis section accessions analyzed, all obtained from Dr. José F. M. Valls of the Brazilian agricultural company Empresa Brasileira de Agropecuria (Embrapa), Centro Nacional de Recursos Genéticos (CENARGEN), Brasília, DF, Brazil.

Table 1 - The Arachis section accessions analyzed.

\begin{tabular}{|c|c|c|c|c|c|}
\hline $\begin{array}{l}\text { Arachis species and describing author(s) } \\
\text { (subspecies/variety) }\end{array}$ & $\begin{array}{l}\text { Genome } \\
\text { type }\end{array}$ & $\begin{array}{c}\text { Accession } \\
\text { number }^{\mathrm{a}}\end{array}$ & $\begin{array}{l}\text { Brazilian (BRA) } \\
\text { accession number }\end{array}$ & $\begin{array}{c}\text { Site }^{\mathrm{b}} \\
\text { (map reference) }\end{array}$ & $\begin{array}{l}\text { Number of } \\
\text { specimens }\end{array}$ \\
\hline A. aff. Cardenasii & & V13721 & 033723 & MT (1609 S; 05827 W) & 02 \\
\hline A. aff. Diogoi & & V13774 & 033863 & MT (1554 S; $05931 \mathrm{~W})$ & 01 \\
\hline \multirow[t]{2}{*}{ A. aff. Simpsonii } & & V13745 & 033782 & MT (1616 S; 05922 W ) & 01 \\
\hline & & V13746 & 033791 & MT (1616 S; $05922 \mathrm{~W}$ ) & 01 \\
\hline A. batizocoi ${ }^{1}$ Krapov. \& Gregory & $\mathrm{B}$ & K9484 & 011335 & BOL (2005 S; $06314 \mathrm{~W})$ & 01 \\
\hline A. cardenasii ${ }^{1}$ Krapov \& Gregory & A & G10017 & 013404 & BOL (1820 S; $05946 \mathrm{~W})$ & 04 \\
\hline A. cruziana Krapov, Gregory \& Simpson & $\mathrm{B}$ & Wi1302 & 036919 & $\operatorname{BOL}\left(\right.$ n.a. $\left.{ }^{\mathrm{c}}\right)$ & 01 \\
\hline \multirow[t]{2}{*}{ A. decora Krapov, Gregory \& Valls } & $2 \mathrm{n}=18$ & V9953 & 022985 & GO (1301 S; $04642 \mathrm{~W})$ & 01 \\
\hline & & V13290 & 030902 & GO (1318 S; $04642 \mathrm{~W})$ & 01 \\
\hline A. diogoi Hoehne & $\mathrm{A}$ & Vp5000 & 039144 & MS (n.a. ) & 01 \\
\hline A. duranensis Krapov \& Gregory & A & V14167 & 022608 & ARG (2445 S; $06526 \mathrm{~W})$ & 01 \\
\hline \multirow[t]{2}{*}{ A. glandulifera Stalker } & $\mathrm{D}$ & V13738 & 033774 & MT (1613 S; 05903 W) & 01 \\
\hline & & V14730 & 038687 & MT (n.a.) & 01 \\
\hline \multirow[t]{4}{*}{ A. gregoryi $^{\mathrm{d}}$} & n.a. & V14728 & 038679 & MT (n.a.) & 01 \\
\hline & & V14739 & 038717 & MT (n.a.) & 01 \\
\hline & & V14760 & 038792 & MT (n.a.) & 01 \\
\hline & & V6389 & 012696 & MT (1519 S; 06006 W ) & 01 \\
\hline \multirow[t]{3}{*}{ A. helodes Mart. ex Krapov \& Rigoni } & A & Co6862 & 018619 & MT (n.a.) & 04 \\
\hline & & V6325 & 012505 & MT (1552 S; $05604 \mathrm{~W})$ & 07 \\
\hline & & V10470 & 024937 & n.a. & 03 \\
\hline \multirow[t]{3}{*}{ A. hoehnei Krapov \& W.C. Gregory } & A & V9140 & 022641 & MS (1917 S; 05722 W ) & 01 \\
\hline & & V9146 & 022659 & MS (1914 S; 05716 W ) & 01 \\
\hline & & V13985 & 034606 & MS (1931 S; 05725 W ) & 01 \\
\hline \multirow{5}{*}{$\begin{array}{r}\text { A. hypogaea Linnaeus (fastigiata/fastigiata) } \\
\text { (fastigiata/fastigiata) }\end{array}$} & $\mathrm{AB}$ & URY85209 & 026999 & URY (n.a.) & 01 \\
\hline & & V10522 & 025097 & SC (n.a.) & 01 \\
\hline & & Mde1640 & 037427 & EQU (n.a.) & 01 \\
\hline & & Mde1560 & 037401 & EQU (n.a.) & 01 \\
\hline & & URY85183 & 026794 & URY (n.a.) & 01 \\
\hline
\end{tabular}


Table 1 (cont.)

\begin{tabular}{|c|c|c|c|c|c|}
\hline $\begin{array}{l}\text { Arachis species and describing author(s) } \\
\text { (subspecies/variety) }\end{array}$ & $\begin{array}{c}\text { Genome } \\
\text { type }\end{array}$ & $\begin{array}{l}\text { Accession } \\
\text { number }^{\mathrm{a}}\end{array}$ & $\begin{array}{l}\text { Brazilian (BRA) } \\
\text { accession number }\end{array}$ & $\begin{array}{c}\text { Site }^{\mathrm{b}} \\
\text { (map reference) }\end{array}$ & $\begin{array}{l}\text { Number of } \\
\text { specimens }\end{array}$ \\
\hline (fastigiata/vulgaris) & & URY85062 & 026239 & URY (n.a.) & 01 \\
\hline (fastigiata/vulgaris) & & URY85273 & 027251 & URY (n.a.) & 01 \\
\hline (hypogaea/hypogaea) & & $\operatorname{Pd} 3147$ & 039229 & RS (n.a.) & 01 \\
\hline (hypogaea/hypogaea) & & V12577 & 030775 & MS (n.a.) & 01 \\
\hline (hypogaea/hypogaea) & & V12548 & 030708 & MT (n.a.) & 01 \\
\hline (hypogaea/hypogaea) & & $\operatorname{Pd} 3324$ & 029807 & PA (n.a.) & 01 \\
\hline (n.a.) & & As433 & n.a. & n.a. & 01 \\
\hline (n.a.) & & Mde1600 & n.a. & n.a. & 01 \\
\hline (n.a.) & & Mde1670 & n.a. & n.a. & 01 \\
\hline (n.a.) & & W725 & n.a. & n.a. & 01 \\
\hline A. ipaënsis Krapov \& Gregory & $\mathrm{B}$ & K30076 & 036234 & BOL (2100 S; $06325 \mathrm{~W}$ ) & 01 \\
\hline A. kempff-mercadoi: Krapov, Gregory \& Simpson & A & V13250 & 030643 & BOL (1745 S; $06310 \mathrm{~W}$ ) & 01 \\
\hline \multirow[t]{5}{*}{ A. kuhlmannii Krapov \& Gregory } & A & V9394 & 022629 & n.a. & 01 \\
\hline & & V6404 & 012653 & MT (1537 S; $05848 \mathrm{~W})$ & 01 \\
\hline & & V8887 & 020206 & MT (1537 S; $05848 \mathrm{~W}$ ) & 01 \\
\hline & & V6352 & 012611 & MT (1556 S; 05748 W ) & 01 \\
\hline & & V9479 & 22586 & MS (1955 S; $05530 \mathrm{~W})$ & 01 \\
\hline \multirow[t]{5}{*}{ A. magna Krapov, Gregory \& Simpson } & $\mathrm{B}$ & K30097 & 036871 & BOL (1622 S; $06058 \mathrm{~W}$ ) & 01 \\
\hline & & V13751 & 033812 & MT (1616 S; 05927 W ) & 01 \\
\hline & & V13748 & 033804 & MT (1616 S; 05924 W ) & 01 \\
\hline & & V13761 & 033847 & MT (1521 S; 06004 W) & 01 \\
\hline & & V14744 & 038741 & MT (n.a.) & 01 \\
\hline \multirow[t]{2}{*}{ A. microsperma Krapov, Gregory \& Valls } & A & V8711 & 020397 & MS (2205 S; $05631 \mathrm{~W})$ & 01 \\
\hline & & V7681 & 017655 & MS (2206 S; $05631 \mathrm{~W})$ & 01 \\
\hline A. monticola Krapov \& Rigoni & $\mathrm{AB}$ & V14165 & 036188 & ARG (2407 S; $06573 \mathrm{~W})$ & 01 \\
\hline A. palustris Krapov, Gregory \& Valls & $2 \mathrm{n}=18$ & V13023 & 030058 & TO (0725 S; 04737 W ) & 01 \\
\hline A. praecox Krapov, Gregory \& Valls & $2 \mathrm{n}=18$ & V13777 & n.a. & n.a. & 01 \\
\hline A. schininii ${ }^{\mathrm{d}}$ & A & V9923 & 022926 & PRY (2223 S; $05620 \mathrm{~W}$ & 02 \\
\hline \multirow[t]{2}{*}{ A. simpsonii Krapov \& Gregory } & A & V13728 & 033740 & BOL (1619 S; 05826 W ) & 01 \\
\hline & & V13732 & 034037 & MT (1557 S; 05845 W ) & 01 \\
\hline A. stenosperma: Krapov \& Gregory & A & V10309 & 024830 & MT (1628 S; 05439 W ) & 01 \\
\hline A. valida Krapov \& Gregory & $\mathrm{B}$ & V13516 & 032646 & MS (1904 S; 05729 W ) & 01 \\
\hline A. villosa Benth. & A & V12812 & 030813 & URY (3016 S; $05737 \mathrm{~W}$ ) & 07 \\
\hline
\end{tabular}

${ }^{a} A s$ - A. O. Scariot; $C o$ - L. Coradin; $G$ - W.C. Gregory; $K$ - A. Krapovickas; $P d$ - G. Pedralli; $S v$ - G.P. Silva; $V$ - J.F.M. Valls; $V p$ - V. Pott; $W$ - W.L. Werneck; $W i$ - D.E. Williams; ${ }^{b}$ Key: ARG = Argentina; $\mathrm{BOL}=$ Bolivia; $\mathrm{ECU}=$ Ecuador. Brazilian states: GO = Goiás; MS = Mato Grosso do Sul; $\mathrm{MT}=$ Mato Grosso; PA = Pará; PRY = Paraguay; $\mathrm{RS}=$ Rio Grande do Sul; $\mathrm{SC}=$ Santa Catarina; $\mathrm{TO}=$ Tocantins; URY $=$ Uruguay. ${ }^{\mathrm{c}} \mathrm{n} . \mathrm{a} .=$ not available. dundescribed species.

DNA extraction, microsatellite loci and amplification

The DNA of each plant was extracted from leaves by the procedure of Doyle and Doyle (1987) as modified by Grattapaglia and Sederoff (1994), diluted in Tris EDTA buffer (10 $\mathrm{mM}$ Tris- $\mathrm{HCl} \mathrm{mM}$ and $1 \mathrm{mM}$ EDTA), quantified in $0.8 \%(\mathrm{w} / \mathrm{v})$ agarose gels based on comparison to known DNA dilutions and diluted to $5 \mathrm{ng} / \mu \mathrm{L}$.
Fourteen microsatellite prime pairs (Table 2) from genomic libraries were used, three (Ag117, Ag140 and Ag171) from Arachis glabrata (Rhizomatosae section), eight (Ah3, Ah7, Ah11, Ah30, Ah6-125, Ah 126, Ah282 and Ah283) from A. hypogaea and three (Ap32, Ap38 and Ap40) from Arachis pintoi (Caulorrhizae section). 
Table 2 - Microsatellite loci analyzed, motifs, primer sequences, expected length in the focal species, $\mathrm{MgCl}_{2}$ concentration per reaction, annealing temperatures, number of alleles per locus and observed (Ho) and expected (He) heterozygosity values.

\begin{tabular}{|c|c|c|c|c|c|c|c|c|c|}
\hline Locus & Motif & Primer sequences & $\begin{array}{l}\text { Length } \\
\text { (bp) }\end{array}$ & Range & $\begin{array}{l}\mathrm{MgCl}_{2} \\
(\mathrm{mM})\end{array}$ & $\begin{array}{l}\mathrm{AT} \\
\left({ }^{\circ} \mathrm{C}\right)\end{array}$ & $\begin{array}{l}\text { Number } \\
\text { of alleles }\end{array}$ & $\mathrm{H}_{0}$ & $\mathrm{H}_{\mathrm{e}}$ \\
\hline $\mathrm{Ah} 3$ & $\begin{array}{l}(\mathrm{GA})_{15}(\mathrm{AG})_{7} \\
(\mathrm{GT})_{7}(\mathrm{GA})_{7}\end{array}$ & $\begin{array}{l}\text { 5'TCGGAGAACCAAGCACACATC3' } \\
\text { 5'TTGCGCTCTTTCTCACACTC3' }\end{array}$ & 202 & $176-255$ & 1.5 & 50 & 28 & 0.2692 & 0.9313 \\
\hline Ah7 & $(\mathrm{TG})_{8}$ & $\begin{array}{l}\text { 5'CAGAGTCGTGATTTGTGCACTG3' } \\
\text { 5'ACAGAGTCGGCCGTCAAGTA3' }\end{array}$ & 102 & $102-110$ & 1.5 & 50 & 9 & 0.3580 & 0.7983 \\
\hline Ah11 & $(\mathrm{TTA})_{15}$ & $\begin{array}{l}\text { 5'AAATAATGGCATACTTGTGAACAATC3' } \\
\text { 5'TTCCACCCAAGGCAAGACTATG3' }\end{array}$ & 176 & $140-204$ & 2.5 & 55 & 29 & 0.0909 & 0.9219 \\
\hline $\operatorname{Ah} 30$ & $(\mathrm{GA})_{9}$ & $\begin{array}{l}\text { 5'TGCTCTTCTTTTCCTTTTCAC3', } \\
\text { 5'AACGGCCAAAACTGAAATTA3' }\end{array}$ & 123 & $121-138$ & 2.0 & 50 & 13 & 0.2388 & 0.8946 \\
\hline Ah6-125 & $(\mathrm{TTC})_{13}$ & $\begin{array}{l}\text { 5'TCGTGTTCCCGATTGCC3' } \\
\text { 5'GCTTTGAACATGAACATGCC3' }\end{array}$ & 180 & $170-210$ & 2.0 & 60 & 20 & 0.1013 & 0.8972 \\
\hline Ah126 & $(\mathrm{GA})_{8 . .} .(\mathrm{GA})_{9}$ & $\begin{array}{l}\text { 5'CCCTGCCACTCTCACTCACT3 } \\
\text { 5'CGTACAAGTCAGGGGGTGAC3', }\end{array}$ & 187 & $180-216$ & 1.5 & 60 & 23 & 0.3250 & 0.9139 \\
\hline Ah282 & $(\mathrm{TA})_{4 . .}(\mathrm{TG})_{45}$ & $\begin{array}{l}\text { 5'GCAAACACACCACATTTCA3', } \\
\text { 5'GGCTCCAATCCCAAACACTA3' }\end{array}$ & 213 & $182-210$ & 1.5 & 45 & 21 & 0.2840 & 0.9352 \\
\hline Ah283 & $(\mathrm{AT})_{8}(\mathrm{GT})_{13}$ & $\begin{array}{l}\text { 5'GGGGTTCGAAGCTTAATTCC3' } \\
\text { 5'CAAGAGCAACTCAATCTTCCTAGA3', }\end{array}$ & 198 & $160-168$ & 2.5 & 55 & 6 & 0.2125 & 0.6965 \\
\hline Ap32 & $(\mathrm{TC})_{19}$ & $\begin{array}{l}\text { 5'GATCATGCTCATCATCAACACC3' } \\
\text { 5'ATAGGGAGAAGGCAGGGAGA3' }\end{array}$ & 170 & 150 & 2.5 & 50 & 1 & 0.0000 & 0.0000 \\
\hline Ap38 & $(\mathrm{CT})_{25}$ & $\begin{array}{l}\text { 5'GCGAACAAAGGAGGAAGAGA3', } \\
\text { 5'GCGAACAAAGGAGGAAGAGA3' }\end{array}$ & 154 & 154 & 2.0 & 55 & 1 & 0.0000 & 0.0000 \\
\hline Ap $40^{\mathrm{b}}$ & $(\mathrm{TC})_{17}$ & $\begin{array}{l}\text { 5'CTGTTTGATCGCCGCTATG3' } \\
\text { 5'GTCAAGTGCTTCCTCCGATG3' }\end{array}$ & 178 & $164-220$ & 2.0 & 50 & 34 & 0.2152 & 0.9410 \\
\hline Ag117 & $(\mathrm{GA})_{19 . .} .(\mathrm{AG})_{18}$ & $\begin{array}{l}\text { 5'GAATGACAGAGTGAGAGTCCA3' } \\
\text { 5'TCAACAAGTTAGTTACCATTAGTTT3' }\end{array}$ & 241 & 250 & 2.5 & 50 & 1 & 0.0000 & 0.0000 \\
\hline Ag140 & $(\mathrm{GA})_{28}$ & $\begin{array}{l}\text { 5'CAGCATTCAATTCAGTTTCG3' } \\
\text { 5'TCAACCTCGAACACACAAAA3', }\end{array}$ & 157 & $124-144$ & 2.5 & 50 & 11 & 0.2099 & 0.7873 \\
\hline Ag171 & $(\mathrm{GA})_{22}$ & $\begin{array}{l}\text { 5'TGACCGTTGGGGTTTTTG3' } \\
\text { 5'CAAACCCAAACACACGTCAC3', }\end{array}$ & 197 & $166-186$ & 2.0 & 50 & 15 & 0.2267 & 0.8374 \\
\hline
\end{tabular}

${ }^{a}$ Described by Hopkins et al. (1999); ${ }^{b}$ Described by Palmieri et al. (2002). AT: Annealing temperature.

Amplifications were performed using a PTC100 thermal cycler (MJ Research, San Francisco). Reactions were carried out in a total volume of $10 \mu \mathrm{L}$ and contained $15 \mathrm{ng}$ of template DNA, $0.17 \mu \mathrm{M}$ of each primer, $0.22 \mathrm{mM}$ of each dNTP, $1 \mathrm{X}$ of reaction buffer, $1 \mathrm{U}$ of Taq DNA polymerase (Amersham Biosciences, Piscataway) and from 1.5 to $2.5 \mathrm{mM} \mathrm{MgCl}_{2}$ (Table 2). The amplification cycle consisted of an initial denaturation step at $94{ }^{\circ} \mathrm{C}$, followed by 32 cycles of $94{ }^{\circ} \mathrm{C}$ for $25 \mathrm{~s} ;\left(45^{\circ} \mathrm{C}\right.$ to $60^{\circ} \mathrm{C}$ ) for $25 \mathrm{~s}$ (Table 2) and $72{ }^{\circ} \mathrm{C}$ for $25 \mathrm{~s}$ and a final $10 \mathrm{~min}$ extension step at $72{ }^{\circ} \mathrm{C}$. The annealing temperatures ranged according to the sequence of the primers (Table 2). The fragments were separated on 4\% (w/v) acrylamide gels (19 acrylamide: 1 bis acrylamide) and the gels were silver stained (Promega, 1995) and photographed under white light.

\section{Data analysis}

The size of each allele was estimated using the 'EagleSight' software version 3.22 (Stratagene, Austin). Expected $(\mathrm{He})$ and observed (Ho) heterozygosities, genetic distances and number of alleles/locus were calculated with the Population Genetic Analysis program (PopGene, version 1.21 - Yeh et al., 1997). A dendrogram was obtained by using the TreeCon for Windows program (version 1.3b; Van de Peer and De Wachter, 1994) that uses the Nei and Li's coefficient. The mean estimated number of repeats in each locus was calculated based on the expected length of fragment and the motif of each locus in focal species.

\section{Results}

All 14 loci allowed the amplification of microsatellite loci in all the Arachis section species analyzed, eleven loci being polymorphic (78\%) and three monomorphic (22\%). Two of the monomorphic loci (Ap32 and Ap38) were isolated from the Caulorrhizae section species A. pintoi and one monomorphic loci (Ag117) from the Rhizomatosae section species $A$. glabrata.

We detected 201 putative alleles at the polymorphic loci Ah3, Ah7, Ah11, Ah30, Ah6-125, Ah126, Ah282, Ah283, Ag140, Ag171 and Ap40, with a mean of 18.3 alleles per polymorphic locus which ranged from six for locus Ah283 to 34 for the Ap40 locus (Table 2). The number 
of alleles per locus varied according to the origin of the primer, with the eight $A$. hypogaea primers detecting 144 alleles (18 per locus), the three $A$. pintoi primers 35 alleles ( 11.7 per locus) and the three $A$. glabrata primers 25 alleles (8.3 per locus).

The mean observed heterozygosity for the 11 polymorphic loci was 0.2301 , the highest value $(0.3580)$ being that for Ah7 locus and the lowest (0.0909) for the Ah11 locus (Table 2).

The mean number of repeats at the polymorphic loci in the non-focal species was estimated on the basis of observed fragment sizes (Table 3). Variation in the repeat number was very wide, ranging from two repeats at the Ah283 locus to 53 at the Ah3 locus.

We also calculated the variability indices for species with multiple accessions or multiple samples of one acces- sion (Table 4). The average number of different alleles per locus ranged from 1.14 in Arachis schininii (undescribed species) to 4.14 in Arachis helodes and the mean expected heterozygosity $\left(\overline{\mathrm{H}}_{\mathrm{e}}\right)$ ranged from 0.0446 in $A$. schininii to 0.4706 in A. helodes.

Some individual plants had banding patterns composed of two fragments (Figure 1), such plants being analyzed as heterozygous since microsatellites are codominant and allow the detection of both alleles in a locus and because most species analyzed were diploid and hence the maximum number of different alleles in a locus was two. The mean observed heterozygosity values $\left(\overline{\mathrm{H}}_{0}\right)$ ranged from 0 for the Arachis species cardenasii, gregoryi, magna and simpsonii to 0.1179 for Arachis kuhlmannii. (Table 4).

Relationships between accessions based on the data for the 14 loci analyzed are presented in Figure 2. As can be

Table 3 - Number of alleles in the polymorphic loci (A) and mean estimated number of repeats (R) in each locus evaluated in the Arachis species.

\begin{tabular}{|c|c|c|c|c|c|c|c|c|c|c|c|c|c|c|c|c|c|c|c|c|c|c|}
\hline \multirow[t]{3}{*}{ Species } & \multicolumn{22}{|c|}{ Loci } \\
\hline & \multicolumn{2}{|c|}{ Ah3 } & \multicolumn{2}{|c|}{ Ah7 } & \multicolumn{2}{|c|}{ Ah11 } & \multicolumn{2}{|c|}{ Ah282 } & \multicolumn{2}{|c|}{ Ah126 } & \multicolumn{2}{|c|}{ Ah6-125 } & \multicolumn{2}{|c|}{ Ah283 } & \multicolumn{2}{|c|}{ Ag140 } & \multicolumn{2}{|c|}{ Ag171 } & \multicolumn{2}{|c|}{ Ap40 } & \multicolumn{2}{|c|}{ Ah30 } \\
\hline & A & $\mathrm{R}$ & A & $\mathrm{R}$ & A & $\mathrm{R}$ & A & $\mathrm{R}$ & A & $\mathrm{R}$ & A & $\mathrm{R}$ & A & $\mathrm{R}$ & A & $\mathrm{R}$ & A & $\mathrm{R}$ & A & $\mathrm{R}$ & A & $\mathrm{R}$ \\
\hline A. aff. cardenasii & 1 & 30 & 1 & 11 & 2 & 14 & 2 & 43 & 2 & 28 & 2 & 23 & 2 & 3 & 3 & 14 & 1 & 8 & 1 & 20 & 1 & 15 \\
\hline A. aff. diogoi & 1 & 33 & 1 & 7 & 2 & 6 & 1 & 39 & 2 & 27 & 2 & 15 & 1 & 4 & 1 & 19 & 1 & 7 & 1 & 16 & 1 & 15 \\
\hline A. aff. simpsonii & 2 & 36 & 2 & 8 & 2 & 9 & 2 & 41 & 2 & 30 & 2 & 14 & 2 & 3 & 2 & 21 & 2 & 8 & 2 & 18 & 2 & 13 \\
\hline A. batizocoi & 1 & 47 & 1 & 9 & 1 & 9 & 1 & 37 & 1 & 28 & 1 & 20 & 1 & 4 & 1 & 17 & 1 & 11 & 1 & 15 & 1 & - \\
\hline A. cardenasii & 1 & 27 & 1 & 8 & 1 & 11 & 2 & 38 & 1 & 18 & 3 & 22 & 1 & 2 & 2 & 13 & 1 & 7 & 1 & 27 & 1 & 15 \\
\hline A. cruziana & 1 & 47 & 1 & 3 & 1 & 12 & 1 & 39 & 1 & 26 & 1 & 24 & 1 & 5 & 1 & 17 & 1 & 8 & 1 & 16 & 1 & 8 \\
\hline A. decora & 2 & 53 & 2 & 9 & 2 & 8 & 2 & 37 & 2 & 25 & 2 & 26 & 1 & 4 & 1 & 21 & 1 & 7 & 3 & 22 & 1 & 8 \\
\hline A. diogoi & 1 & 32 & 1 & 7 & 1 & 11 & 1 & 33 & 1 & 19 & 1 & 15 & 1 & 4 & 1 & 17 & 1 & 6 & 1 & 10 & 1 & 8 \\
\hline A. duranensis & 1 & 36 & 1 & 8 & - & - & 1 & 44 & 1 & 25 & 1 & 24 & 1 & 6 & 1 & 15 & - & - & 1 & 20 & 1 & 15 \\
\hline A. glandulifera & 2 & 44 & 3 & 9 & 2 & 15 & 2 & 36 & 3 & 25 & 2 & 12 & 2 & 5 & 1 & 17 & 2 & 9 & 2 & 32 & 1 & 13 \\
\hline A. gregoryi & 3 & 48 & 3 & 9 & 4 & 13 & 3 & 37 & 3 & 25 & 2 & 18 & 2 & 4 & 2 & 16 & 4 & 7 & 3 & 13 & 2 & 11 \\
\hline A. helodes & 4 & 35 & 4 & 9 & 5 & 9 & 10 & 39 & 5 & 26 & 8 & 23 & 2 & 2 & 3 & 12 & 3 & 12 & 8 & 23 & 4 & 16 \\
\hline A. hoehnei & 2 & 32 & 2 & 8 & 2 & 3 & 2 & 42 & 2 & 33 & 2 & 23 & 1 & 2 & 2 & 14 & 2 & 15 & 2 & 11 & 1 & 13 \\
\hline A. hypogaea & 10 & 37 & 2 & 8 & 6 & 20 & 2 & 41 & 2 & 23 & 1 & 23 & 2 & 4 & 2 & 16 & 2 & 7 & 2 & 17 & 2 & 10 \\
\hline A. ipaënsis & 1 & 37 & 1 & 8 & 1 & 21 & 1 & 38 & 1 & 29 & 1 & 20 & 1 & 4 & 1 & 17 & 1 & 8 & 1 & 13 & 1 & 15 \\
\hline A. kempff-mercadoi & 1 & 38 & 1 & 10 & 1 & 19 & 1 & 42 & 1 & 29 & 1 & 22 & 1 & 2 & 1 & 15 & 1 & 9 & 1 & 30 & - & - \\
\hline A. kuhlmannii & 5 & 38 & 4 & 8 & 6 & 9 & 5 & 39 & 4 & 21 & 2 & 18 & 2 & 2 & 1 & 13 & 4 & 9 & 3 & 21 & 3 & 13 \\
\hline A. magna & 3 & 40 & 1 & 8 & 5 & 17 & 4 & 38 & 6 & 25 & 4 & 23 & 2 & 4 & 2 & 16 & 4 & 9 & 3 & 15 & 3 & 12 \\
\hline A. microsperma & 2 & 37 & 1 & 8 & 1 & 17 & 3 & 42 & 1 & 17 & 1 & 15 & 1 & 4 & 1 & 17 & 1 & 7 & 2 & 36 & 2 & 14 \\
\hline A. monticola & 2 & 38 & 2 & 8 & 2 & 24 & 2 & 40 & 2 & 23 & 1 & 18 & 2 & 4 & 2 & 16 & 2 & 7 & 1 & 24 & 2 & 10 \\
\hline A. palustris & 1 & 37 & 1 & 8 & 1 & 20 & 1 & 40 & 1 & 23 & 1 & 17 & 1 & 4 & 1 & 14 & 1 & 7 & 1 & 16 & 1 & 8 \\
\hline A. praecox & 1 & 48 & 1 & 11 & 1 & 36 & 1 & 37 & 1 & 25 & 1 & 20 & - & - & 1 & 21 & 1 & 8 & 1 & 15 & 1 & 8 \\
\hline A. schininii & 1 & 38 & 3 & 9 & 1 & 6 & 1 & 41 & 1 & 17 & 1 & 22 & 1 & 2 & 1 & 14 & 1 & 14 & 1 & 30 & 1 & 16 \\
\hline A. simpsonii & 2 & 33 & 2 & 8 & 2 & 14 & 2 & 41 & 1 & 31 & 2 & 22 & 2 & 2 & 2 & 19 & 2 & 10 & 3 & 26 & 2 & 14 \\
\hline A. stenosperma & 1 & 37 & 1 & 9 & 1 & 16 & 1 & 40 & 1 & 28 & 1 & 27 & 1 & 6 & 1 & 17 & 1 & 9 & 1 & 27 & 1 & 13 \\
\hline A. valida & 1 & 47 & 1 & 7 & 1 & 26 & 1 & 29 & 1 & 27 & 1 & 17 & 1 & 5 & 1 & 20 & 1 & 9 & 1 & 27 & 1 & 15 \\
\hline A. villosa & 3 & 28 & 3 & 9 & 2 & 14 & 1 & 45 & 1 & 17 & 4 & 23 & 2 & 5 & 3 & 16 & 2 & 8 & 2 & 24 & 1 & 19 \\
\hline Average & & 38 & & 8 & & 15 & & 39 & & 25 & & 21 & & 4 & & 16 & & 9 & & 21 & & 13 \\
\hline
\end{tabular}


Table 4 - Number of samples analyzed, average number of different alleles per locus, mean observed heterozygosity $\left(\overline{\mathrm{H}}_{0}\right)$ and mean expected heterozygosity $\left(\overline{\mathrm{H}}_{\mathrm{e}}\right)$.

\begin{tabular}{lcccc}
\hline Species & $\begin{array}{c}\text { Number of } \\
\text { samples }\end{array}$ & $\begin{array}{c}\text { Average num- } \\
\text { ber of alleles }\end{array}$ & $\overline{\mathrm{H}}_{\mathrm{e}}$ & $\overline{\mathrm{H}}_{0}$ \\
\hline A. aff cardenasii & 2 & 1.38 & 0.1346 & 0.0769 \\
A. aff. simpsonii & 2 & 1.78 & 0.3929 & 0.0000 \\
A. cardenasii & 4 & 1.28 & 0.0982 & 0.0000 \\
A. decora & 2 & 1.57 & 0.2589 & 0.0357 \\
A. glandulifera & 2 & 1.78 & 0.3393 & 0.1071 \\
A. gregoryi & 4 & 2.43 & 0.4514 & 0.0000 \\
A. helodes & 14 & 4.14 & 0.4706 & 0.0997 \\
A. hoehnei & 3 & 1.57 & 0.2738 & 0.0714 \\
A. hypogaea & 15 & 2.78 & 0.4700 & - \\
A. kuhlmannii & 5 & 2.93 & 0.4615 & 0.1179 \\
A. magna & 5 & 2.36 & 0.3829 & 0.0000 \\
A. microsperma & 2 & 1.64 & 0.1875 & 0.0357 \\
A. schinini & 2 & 1.14 & 0.0446 & 0.0357 \\
A. simpsonii & 2 & 1.21 & 0.1071 & 0.0000 \\
A. villosa & 7 & 1.93 & 0.2592 & 0.0663 \\
\hline Average & & 1.99 & 0.2759 & 0.0462 \\
\hline
\end{tabular}

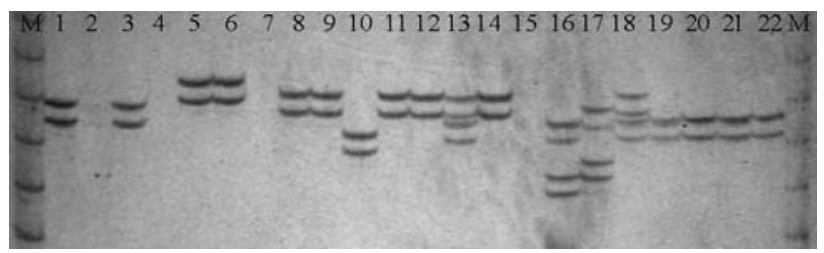

Figure 1 - Silver stained 4\% (w/v) acrylamide gel showing polymorphism at locus Ah282 in plants of Arachis schinini (plants 1 to 3), Arachis hoehnei (plants 4 to 8 ) and Arachis helodes (plants 9 to 22). The number of fragments in the plants ranged from two (plants 1, 3, 5, 6, 8, 9, 11, 12, 14, $19,20,21,22$ ) to four (plants $13,16,17,18$ ). It can also be seen that some plants (17 and 19) from the same species did not share any fragment with each other. $\mathrm{M}=$ molecular weight.

seen, all accessions were characterized and the diversity between accessions of a particular species was very high. Many accessions were grouped according to the species to which they belonged with, for instance, A. helodes and $A$. hypogaea) accessions being very related to each other, while some accessions were grouped away from the other accessions of the same species, an example being $A$. hoehnei and A. simpsonii accessions which were placed in different clusters.

\section{Discussion}

Independent of the Arachis species (A. hypogaea, A. glabrata or A. pintoi) from which they were originally developed, all the primers tested allowed the amplification of loci in all the Arachis species analyzed. Primer transferability between the Arachis section species demonstrated that

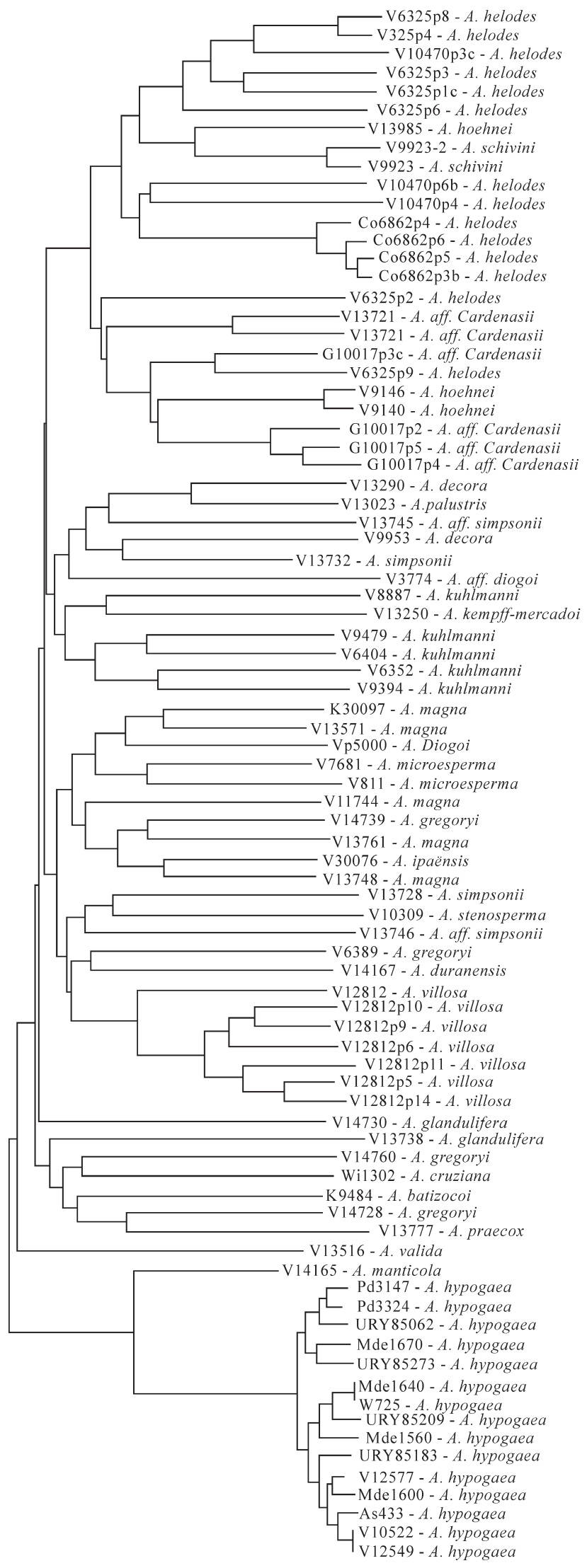

Figure 2 - Dendrogram showing the relationship between 83 plants of 60 genus Arachis accessions. The dendrogram was based on the analysis of 14 microsatellite loci. 
the regions flanking these microsatellites are conserved enough to allow locus amplification, agreeing with previous work by other authors who have shown that microsatellite flanking regions are conserved, being even used to phylogenetic inferences in a number of species (Matsuoka et al., 2002; Rosseto et al., 2002). We found that the percentage of cross-species transferability was very high considering the number of species analyzed and genetic distance among them. Hopkins et al. (1999) who analyzed polymorphism in A. hypogaea using six A. hypogaea microsatellite loci also observed transferability to other Arachis species (A. monticola, A. ipaënsis and A. duranensis), but all of them were closely related to $A$. hypogaea. Likewise, Moretzsohn et al. (2004) investigated 36 Arachis species and observed up to $76 \%$ microsatellite primer transferability to Arachis section species and up to $45 \%$ to species of the other eight sections of the genus Arachis. The different transferability levels between our study and that of Moretzsohn et al. (2004) was probably because we optimized the annealing temperature and $\mathrm{MgCl}_{2}$ concentration while Moretzsohn et al. (2004) optimized only the annealing temperature. Transferability has been observed in many other genera and species, Collevatti et al. (1999) having obtained total transferability of 10 Caryocar brasiliensis microsatellite loci to five other Caryocar species, while Gaitán-Solís et al. (2002) developed 68 Phaseolus vulgaris microsatellite loci and found that the transferability rate to other four other Phaseolus species was almost $50 \%$.

In general the estimated number of repeats in the polymorphic loci in non-focal species were different from the number of repeats found in the same loci in the focal species. For example, the expected allele size of the $A$. hypogaea Ah282 locus was 213 base pairs (bp) with $45 \mathrm{TG}$ repeats (Table 2) while in the species to which it was transferred the estimated repeat number ranged from 29 for Arachis valida to 45 for Arachis villosa (Table 3), showing that this locus was highly polymorphic with 22 alleles. However, on the other hand, locus Ah283 presented 21 repeats in A. hypogaea, two to six repeats in the other species and low polymorphism with only six alleles detected in the whole sample. Our data indicate that the number of repeats as well as the level of polymorphism can vary extensively between focal and non-focal species and that allele length is general longer in focal species than in non-focal species.

Overall, variability levels in the species were moderately high $\left(\overline{\mathrm{H}}_{\mathrm{e}}=0.2759\right)$. The $\overline{\mathrm{H}}_{\mathrm{e}}$ value was high in species for which only a few accessions were analyzed, e.g. Arachis decora $\left(\overline{\mathrm{H}}_{\mathrm{e}}=0.2589\right.$ for two accessions) and $A$. kuhlmannii $\left(\overline{\mathrm{H}}_{\mathrm{e}}=0.4615\right.$ for five accessions). Our results thus indicate that the germplasm of the species analyzed was generally composed of highly contrasting individuals. The genetic variability of diploid Arachis species has been reported in a number of studies using different molecular markers (Galgaro et al., 1998; Gimenes et al., 2002). How- ever, these studies used markers, such as amplified fragment length polymorphism (AFLP) and random amplified polymorphic DNA (RAPD) which score as dominant markers and lead to an underestimation of genetic variability. Furthermore, in the case of RAPD, data integration and comparison are difficult due to the detection of multiple loci and low repetitiveness.

In general, the mean observed heterozygosity found in the Arachis species analyzed was low for all loci, as expected for a self-fertilizing species, indicating that the breeding system of the analyzed species is preferentially autogamous. However, we observed that certain Arachis species (e.g. A. glandulifera, A. helodes and A. kuhlmannii) presented moderate levels of observed heterozygosity, $A$. helodes for example presenting $\overline{\mathrm{H}}_{0}=0.0997$ indicating that, on average, $9.97 \%$ of individual plants analyzed were heterozygous for any the loci analyzed. The frequencies observed in some species such as A. kuhlmannii (11.79\%) clearly show that allogamy or other mechanisms to retain heterozygosity occur in Arachis. Allogamy can have consequences for the conservation of the species germplasm bank since a loss of genetic identity of the species can occur due to pollen contamination.

The genetic relationships between species established based on our microsatellite data (Figure 2) partially agreed with relationships established based on other types of data. For instance, our data placed A. hypogaea and Arachis monticola together, agreeing with previous work showing that they are highly related to each other (Pattee et al., 1998; He and Prakash, 2001). Also, A. magna and A. ipaënsis were located close to each other in our tree (Figure 2) and are known to be morphologically very similar to each other (Krapovickas and Gregory, 1994). Furthermore, the $A$. decora V13290 accession and A. palustris V13023 were placed very close to each other in our tree (Figure 2), supporting our unpublished data which shows that these two species have 18 chromosomes and show no polymorphism on their rDNA transcribed spacers, indicating that they are closely related to each other phylogenetically.

The Arachis species analyzed by us had A, B and D genomes. The A genome species were divided into four groups and the B genome into two groups, with Arachis glandulifera, the only D genome species in the genus (Stalker, 1991), being placed close to the B genome species Arachis batizocoi and Arachis cruziana. Some A genome groups were closer to B genome groups than to other A genome groups. This, and the placement of some accessions away from the other accessions of their species, may have been due to two main factors: the high polymorphism detected in the analyzed loci and/or the occurrence of homoplastic alleles, i.e. alleles that present the same size in a gel, are not identical by descent and are found in relatively distantly related species. In some cases, polymorphism within species was so high that the genetic distance was higher between accessions than between some species. 
This was the case for $A$. simpsonii accessions, which presented a genetic distance (data not shown) of 0.9359 whereas unrelated species such as A. magna and $A$. villosa presented a genetic distance of 0.7506 . This means that these species could not be characterized with the 14 microsatellite markers used in our study and that larger samples, which allow better sampling of intraspecific variation, need to be analyzed.

The microsatellite loci used in this study were quite efficient for the analysis of genetic variability in Arachis section species because they presented high transferability to species from the same genus and they were polymorphic in the species to which they were transferred, thus permitting the analysis of related species without the development of specific primer pairs. The characterization of the genetic variability of the germplasm analyzed could be used to plan sampling programs, and assist in germplasm maintenance and the formation of species 'core collections'. Moreover, codominance and high polymorphism can determine variation in breeding systems. On the other hand, the markers were not efficient in the establishment of genetic relationships between the species investigated in this study, probably due to the very small number of accessions analyzed for some species, high variability among accessions in the loci analyzed and homoplastic fragments.

\section{Acknowledgments}

The authors would like to thank Dr. José F.M. Valls and CENARGEM/EMBRAPA for the plant material, Dr. Edson S. Mori for help with the statistical analysis and Fundação de Amparo a Pesquisa do Estado de São Paulo (FAPESP) for the funding.

\section{References}

Börner A, Chebotar S and Korzum V (2000) Molecular characterization of the genetic integrity of wheat (Triticum aestivum L.) germplasm after long-term maintenance. Theor Appl Genet 100:494-497.

Burow MD, Starr JL, Simpson CE and Paterson AH (1996) Identification of RAPD markers in peanut (Arachis hypogaea) associated with root-knot nematode resistance derived from $A$. cardenasii. Mol Breed 2:307-319.

Collevatti GR, Brondani RPV and Grattapaglia D (1999) Development and characterization of microsatellite markers for genetic analysis of a Brazilian endangered tree species Caryocar brasiliensis. Heredity 83:748-756.

Doyle JJ and Doyle JL (1987) A rapid DNA isolation procedure for small amounts of leaf tissue. Focus 12:13-15.

Gaitán-Solís E, Duque MC, Edwards KJ and Tohme J (2002) Microsatellite repeats in common bean (Phaseolus vulgaris): Isolation, characterization, and cross-species amplification in Phaseolus ssp. Crop Sci 42:2128-2136.

Galgaro L, Lopes CR, Gimenes M, Valls JFM and Kochert G (1998) Genetic variation between several species of sections Extranervosae, Caulorrhizae, Heteranthae, and
Triseminatae (genus Arachis) estimated by DNA polymorphism. Genome 41:445-454.

Garcia GM, Stalker HT and Kochert G (1995) Introgression analysis of an interspecific hybrid population in peanuts (Arachis hypogaea L.) using RFLP and RAPD markers. Genome 38:166-176.

Ghebru B, Schmidt RJ and Bennetzen JL (2002) Genetic diversity of Eritrean sorghum landraces assessed with simple sequence repeats (SSR) markers. Theor Appl Genet 105:229236.

Gimenes MA, Lopes CR and Valls JFM (2002) Genetic relationship among Arachis species based on AFLP. Genet Mol Biol 25:349-353.

Grattapaglia D and Sederoff RR (1994) Genetic linkage maps of Eucalyptus grandis and Eucalyptus urophilla using a pseudo-testcross mapping strategy and RAPD markers. Genetics 137:1121-1137.

Gupta PK and Varshney RK (2000) The development and use of microsatellite markers for genetic analysis and plant breeding with emphasis on bread wheat. Euphytica 113:163-185.

Gregory WC, Krapovickas A and Gregory MP (1980) Structure, variation, evolution and classification in Arachis. In: Summerfiled RJ and Bunting AH (eds) Advances in Legume Science. Royal Botanic Gardens, London, pp 469-481.

He G and Prakash C (2001) Evaluation of genetic relationships among botanical varieties of cultivated peanut (A. hypogaea L.) using AFLP markers. Genet Res Crop Evol 48:347-352.

Hopkins MS, Casa AM, Wang T, Mitchell SE, Dean RE, Kochert $G$ and Kresovich S (1999) Discovery and characterization of polymorphic simple sequence repeats (SSRs) in peanut. Crop Sci 39:1243-1247.

Hormaza JI (2002) Molecular characterization and similarity relationships among apricot (Prunus armeniaca L.) genotypes using simple sequence repeats. Theor Appl Genet 104:321328.

Kochert G, Stalker HT, Gimenes MA, Galgaro L, Lopes CR and Moore K (1996) RFLP and cytogenetic evidence on the origin and evolution of allotetraploid domesticated peanut Arachis hypogaea (Leguminosae). Amer J Bot 83:12821291.

Krapovickas A and Gregory WC (1994) Taxonomia del género Arachis (Leguminosae). Bonplandia 8:1-186.

Matsuoka Y, Mitchell SE, Kresovich S, Goodman M and Doebley $\mathrm{J}$ (2002) Microsatellites in Zea - Variability, patterns of mutations, and use for evolutionary studies. Theor Appl Genet 104:436-450.

Moretzsohn MC, Hopkins MS, Mitchell SE, Kresovich S, Valls JFM and Ferreira ME (2004) Genetic diversity of peanut (Arachis hypogaea L.) and its wild relatives based on the analysis of hypervariable regions of the genome. BMC Plant Biol 4:11.

Palmieri DA, Hoshino AA, Bravo JP, Lopes CR and Gimenes MA (2002) Isolation and characterization of microsatellite loci from the forage species Arachis pintoi (Genus Arachis). Mol Ecol Notes 2:551-553.

Pattee HE, Stalker HT and Giesbrecht FG (1998) Reproductive efficiency in reciprocal crosses of Arachis monticola with $A$. hypogaea subspecies. Peanut Sci 25:7-12.

Plieske J and Struss D (2001) Microsatellite markers for genome analysis in Brassica L. development in Brassica napus and 
abundance in Brassicaceae species. Theor Appl Genet 102:689-694.

Promega (1995) Technical Manual: Silver Sequence DNA Sequencing System. Promega Corp, Madison, 25 pp.

Rosseto M, McNally J and Henry RJ (2002) Evaluating the potential of SSR flanking regions for examining taxonomic relationships in the Vitaceae. Theor Appl Genet 104:61-66.

Singh KP, Raina SN and Singh AK (1996) Variation in chromosomal DNA associated with the evolution of Arachis species. Genome 39:890-897.

Stalker HT (1991) A new species in section Arachis of peanuts with a D genome. Amer J Bot 78:630-637.
Simpson CE and Starr JL (2001) Registration of 'COAN' peanut. Crop Sci 41:918.

Van de Peer Y and De Wachter R (1994) TREECON for Windows:A software package for the construction and drawing of evolutionary trees for the Microsoft Windows environment. Comput Appl Biosci 10:569-570.

Yeh FC, Yang RC, Boiley T, Ye ZH and Mao JX (1997) PopGene, the user-frendly shareware for population genetic analysis. Molecular Biology and Biotechnology Center, University of Alberta.

Weber JL and May P (1989). Abundant class of human DNA polymorphisms which can be typed using the polymerase chain reaction. Am J Hum Gene 44:388-396.

Associate Editor: Márcio de Castro Silva Filho 